\title{
Ten Thousand Thoreaus
}

As a dues-paying member of the restoration community (I mean SER), who really believes that restoration provides a way to solve some of our most serious environmental problems, I resist the tendency toward pessimism that so often characterizes environmentalism. But we all have our darkened windows, as my uncle used to say-in this case, situations that challenge our optimism and that really get on our nerves.

On my short list at the moment: SUVs, the return of billboards to our highways (who can believe it - a bit of the worst of the '50s after a blessed hiatus of some 30 years?) and-especially - the ongoing tend toward urban sprawl and the dream house in the country.

We've all seen this, and many of us, inspired by the likes of Thoreau, Muir and Leopold, have participated in it. In the ' 50 s and ' 60 s we moved to the suburbs. Now, richer and owning more cars, we are moving beyond that, building "homes" (houses, actually) and vacation retreats in the country, indulging a pastoral impulse or taste for the wild that is in many respects as hard on the natural landscape as, well, a shopping mall.

Or maybe even harder. In a recent article in Isthmus, a Madison weekly newspaper, David Cieslewicz, who is director of A Thousand Friends of Wisconsin, an organization that lobbies for environmentally sensible land-use planning, takes exurbanites to task for the waste of land and resources their lifestyle entails. Making his case, Cieslewicz argues that cities are, on balance, good for the environment because, by concentrating populations, they not only save land, they also reduce the use of cars and highways and the appalling waste these entail. Thus he cites a recent study by the Natural Resources Defense Council showing that residents of neighborhoods with a density of eight units per acre (read "downtown") drive about half as many miles as residents of subdivisions with lots of one acre or more.

There is nothing new about an environmentalist deploring urban sprawl. What I find interesting about Cieslewicz's critique is that he lays part of the blame at the feet of environmentalists themselves-and in particular those canonic thinkers, starting with Thoreau, who have to a considerable extent provided the scriptures that have taught the rest of us how to go about developing a healthy relationship with the rest of nature.

This, after all, is what people like Thoreau and Muir and Leopold did-and celebrated. They fled the city and built their houses-or, in Leopold's case, their weekend retreats-in the country, acting out the idea that this is the way to achieve an intimate, harmonious relationship with nature. That wasn't so bad when it was just the odd recluse or college professor. But when the practice gets democratized, and a thousand people show up for an afternoon at the pond, as often happens nowadays at Walden on a warm summer afternoon, or when several thousand buy land in rural Wisconsin for weekend retreats and hobby farms, the result can be a disaster for the rural and wild landscape.

Here in Wisconsin, for example, we are on the verge of widening US Highway 12 north of Madison, the very road Leopold drove to reach his Sand County retreat, recapitulating and extending the destruction of roadside vegetation that Leopold himself mourned in his elegy for the prairie in A Sand County Almanac. It's easy to deplore this and to resent the exurbanites who now commute between city and country. Yet it is only fair to keep in mind that what they are doing is exactly what Leopold himself did, and that, it is only fair to assume, many of them are motivated by the same desire for wildness and contact with nature.

The problem, in other words, lies in the paradigm itself, and in the very rituals that environmentalism has provided for achieving contact and communion with nature. It is not that they are bad in themselves. It is just that they are incomplete. Most of them, from Thoreau's cabin-building and huckleberrying to modern-day birding and backpacking, are essentially consumptive. And besides that to some extent they remove people from the non-voluntary associations that are an essential component of community.

Restoration is important here because it provides the basis for a different paradigm and a different set of rituals—a way of "using" the natural landscape that is constructive rather than consumptive, and that both accommodates and encourages communal action. It is also a way of "doing" nature downtown, making the city more natural, making it a place where one can find and commune with nature without, in Leopold's own despairing phrase, loving it to death.

This, then, is the real challenge for restoration over the next generation: to learn to do restoration in such a way that it offers, for most of us most of the time, a better way of relating to nature and the human community than we can find any other way. Then we can sell our land in the country and move back to town. Or, restore the land and then turn it over to the county, or find some other way to ensure its future as part of an ecological commons-as, in fact, Leopold's children have done with his Sand County land.

Either way, we will have contributed something to an ecologically differentiated landscape that is part urban, part rural and part really wild.

William R. Jordan III 